\title{
Synthesis of an extremely sterically shielding $N$-heterocyclic carbene ligand
}

\author{
Simone G. Weber, Christian Loos, Frank Rominger, and Bernd F. Straub* \\ Institut für Organische Chemie, Ruprecht-Karls-Universität, Im Neuenheimer Feld 270, \\ Heidelberg, Germany \\ E-mail: straub@oci.uni-heidelberg.de
}

Dedicated to Prof. Dr. Rainer Beckert on the occasion of his $60^{\text {th }}$ birthday

\begin{abstract}
The N-heterocyclic carbene (NHC) ligand IPr** features substituents of unprecedented steric demand $\quad\left(I P r^{* *}=1,3\right.$-bis[2,6-bis[(4-tert-butylphenyl)methyl]-4-methylphenyl]imidazol-2ylidene). The NHC structure is an advanced derivative of the IPr system, and of the IPr* by Berthon-Gelloz and Markó. In the IPr** ancillary ligand, two para-methyl are introduced and eight methyl groups of IPr are formally replaced by a 4-tert-butylphenyl substituent, respectively, thereby sterically shielding both a coordinated metal and its second ligand. Favorable features of ligand and late transition metal complexes include high solubility, aesthetic NMR spectra, and a tendency towards crystallization.
\end{abstract}

Keywords: Imidazolium salt, $N$-heterocyclic carbene, palladium complex, single-crystal X-ray diffraction structure, steric shielding

\section{Introduction}

N-Heterocyclic carbenes (NHC) have been increasingly used as ligands, particularly in transition metal complexes for homogenous catalysis. ${ }^{1}$ The main advantages of these ligands are their ability to kinetically stabilize highly reactive low-valent transition metal atoms with low coordination number. ${ }^{2}$ A decisive feature of NHC ligands with ortho-substituted aromatic substituents is their steric shielding of the carbene ligand atom and the metal atom. IPr and its saturated derivative SIPr are typical representatives. Several factors allow the widespread use of the IPr ligand in homogenous catalysis: ${ }^{1}$ its efficient preparation, ${ }^{3}$ the ease of handling of the imidazolium precursor and its tendency to stabilize reactive transition metal intermediates. ${ }^{4}$

The Cavallo group developed the "buried volume" concept to quantify the steric demand of $\mathrm{N}$-heterocyclic carbenes. ${ }^{5}$ The buried volume (in $\% V_{\text {bur }}$ ) gives a measure of the space occupied 
by the NHC ligand in the first coordination sphere of the metal center (see Figure 1). The greater the steric bulk of the NHC, the bigger is its so-called "buried volume". It is important to notice that for the comparison of different buried volumes it is necessary to have the same calculation parameters as the sphere radii and the distance between the metal and the coordination carbene atom. The most cited values for buried volumes were calculated from (NHC)AuCl complexes with a sphere radius " $r$ " of $3.5 \AA$ and a distance "d" between the metal and the carbene of $2.0 \AA$ (Figure 2). ${ }^{6,7}$

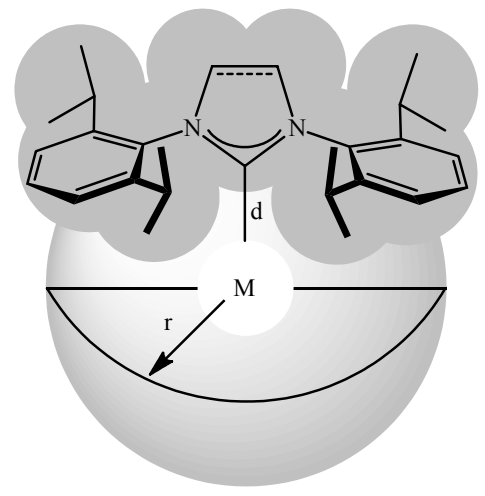

Figure 1. Representation of the sphere for the calculation of buried volume values (here with an IPr complex).
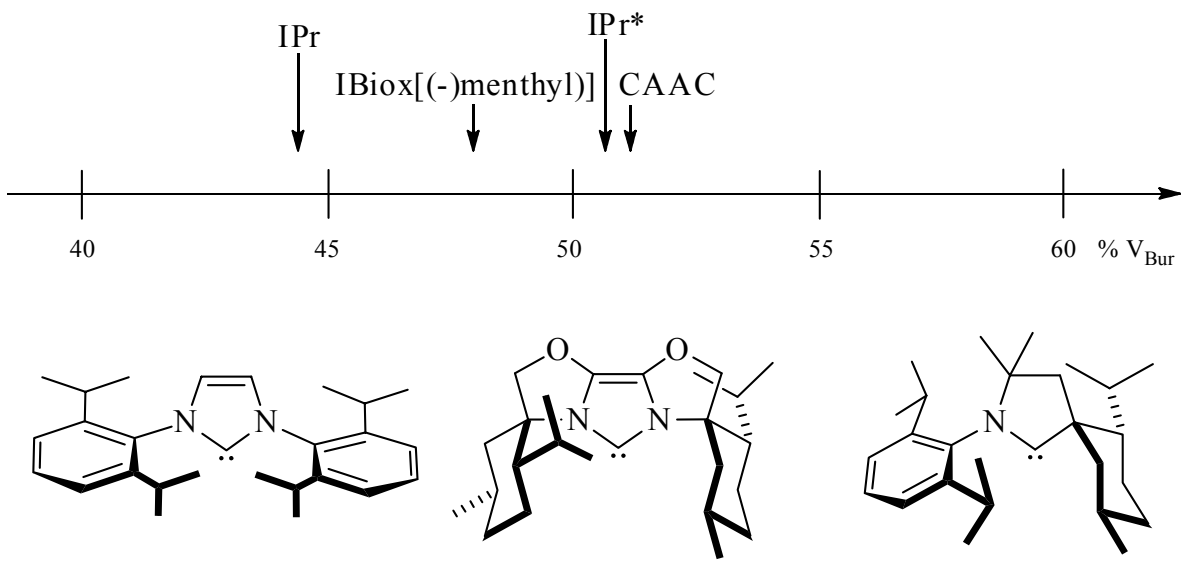

IPr, $44.5 \%\left(V_{\text {bur }}\right) \quad$ IBiox[(-)-menthyl], $47.7 \%\left(V_{\text {bur }}\right) \quad$ CAAC, $51.2 \%\left(V_{\text {bur }}\right)$

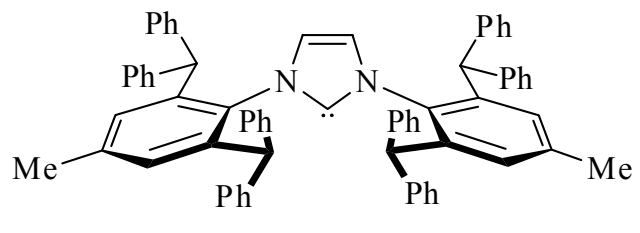

IPr*, $50.4 \%\left(V_{\text {bur }}\right)$

Figure 2. Buried volumes of sterically shielding N-heterocyclic carbene ligands. ${ }^{6,15 a}$ 
Some prominent sterically demanding NHC are displayed in Figure 2. IBiox has been prepared by the Glorius group. ${ }^{8}$ Ligands of the CAAC type have been introduced by the Bertrand group. ${ }^{9,10}$ These ligands stand out due to their "flexible steric bulk", which enables them to influence transition metal catalysts' activities. ${ }^{11,12}$ Berthon-Gelloz and Markó enhanced the IPr system $^{13}$ by formally replacing four isopropyl groups by four benzydryl substituents, and adding two methyl substituents, thereby generating the even bulkier IPr* ligand. ${ }^{14,15 a}$

Analogously, copper and silver complexes of a chiral IPr derivative with four 1-phenylethyl substituents have been prepared in the Gawley group. ${ }^{15 b}$

In this manuscript, we present the synthesis of a new and even more sterically demanding NHC ligand, IPr**, 1,3-bis[2,6-bis[bis-4-tert-butylphenyl)methyl]-4-methylphenyl]imidazol-2ylidene (Figure 3).

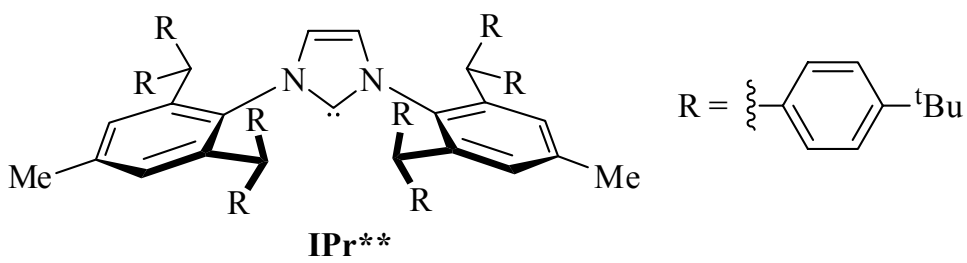

Figure 3. NHC ligand IPr**.

\section{Results and Discussion}

\section{A ligand system tailored for the isolation of reactive intermediates}

Structurally, the IPr** ligand is only an octa-tert-butyl derivative of the IPr* system. Its novelty lies in the so far unique combination of steric demand, favorable spectroscopic features, high solubility, and tendency towards crystallization. The steric bulk of IPr** was tailored to stabilize reactive intermediates, and make possible their synthesis and isolation. Therefore, four of the eight 4-tert-butylphenyl substituents surround the coordinated metal center, and the metal's other ligands. The tert-butyl groups lead to intense signals in ${ }^{1} \mathrm{H}-\mathrm{NMR}$ spectroscopy. The mulitplet signals in the aromatic region of IPr* are significantly simplified: Thus, mixtures of IPr** complexes are easier to analyze. Furthermore, the introduction of tert-butyl groups leads to a higher solubility in organic solvents, rendering possible low-temperature NMR spectroscopy of reactive IPr** complexes in inert solvents. Despite the high solubility, the tendency towards crystallization remains intact, which is relevant for purification and single-crystal X-ray structure analyses.

\section{Synthesis}

The synthesis of the imidazolium chloride precursor salt of IPr** consists of several steps, starting with inexpensive tert-butylbenzene (Scheme 1). The first step is the bromination of tert- 
butylbenzene to 1-brom-4-tert-butylbenzene. ${ }^{16}$ The latter is transformed to the Grignard reagent which reacts in situ with ethyl formate to a benzhydrol derivative. ${ }^{17}$ The following step is the dialkylation of $p$-toluidine with this benzhydrol mediated by concentrated $\mathrm{HCl}$ and $\mathrm{ZnCl}_{2}{ }^{14}{ }^{\mathrm{T}}$ The aniline 1 was obtained in moderate yield on a multigram scale. The further conversion to the diimine 2 was more challenging. Using aqueous glyoxal as a reagent, $\mathrm{MgSO}_{4}$ as a water abstracting agent and dichloromethane as the solvent, only mixtures of the toluidine substrate $\mathbf{1}$ and the product 2 were be observed. ${ }^{14}$ As separation failed, both the solvent and the reaction conditions were modified: The method of Plenio et al. using formic acid as a catalyst and aqueous glyoxal as a reagent in a 1:1 mixture of methyl tert-butyl ether and ethanol initially failed to give access to the desired diimine 2. ${ }^{18}$ However, after heating the reaction mixture to 58 ${ }^{\circ} \mathrm{C}$ for ten days, the diimine precipitated as yellow solid. The diimine product $\mathbf{2}$ precipitated only in a solvent mixture of tert-butyl ether and ethanol, whereas the diimine precursor for IPr* precipitated in dichloromethane. ${ }^{14}$ The reaction time for the diimine precursor of IPr* amounted to only four days. Apparently, the greater steric bulk of the eight additional tert-butyl groups lead to a significant decrease in the reaction rate.

Single-crystal structure analyses were performed for both the toluidine $\mathbf{1}$ and the diimine $\mathbf{2}$ (Figure 4). The final cyclization step towards $\mathrm{IPr}^{* *} \cdot \mathrm{HCl}$ (3) was again accomplished by a modified method of Berthon-Gelloz et al. (Scheme 1 and Figure 5). ${ }^{14}$
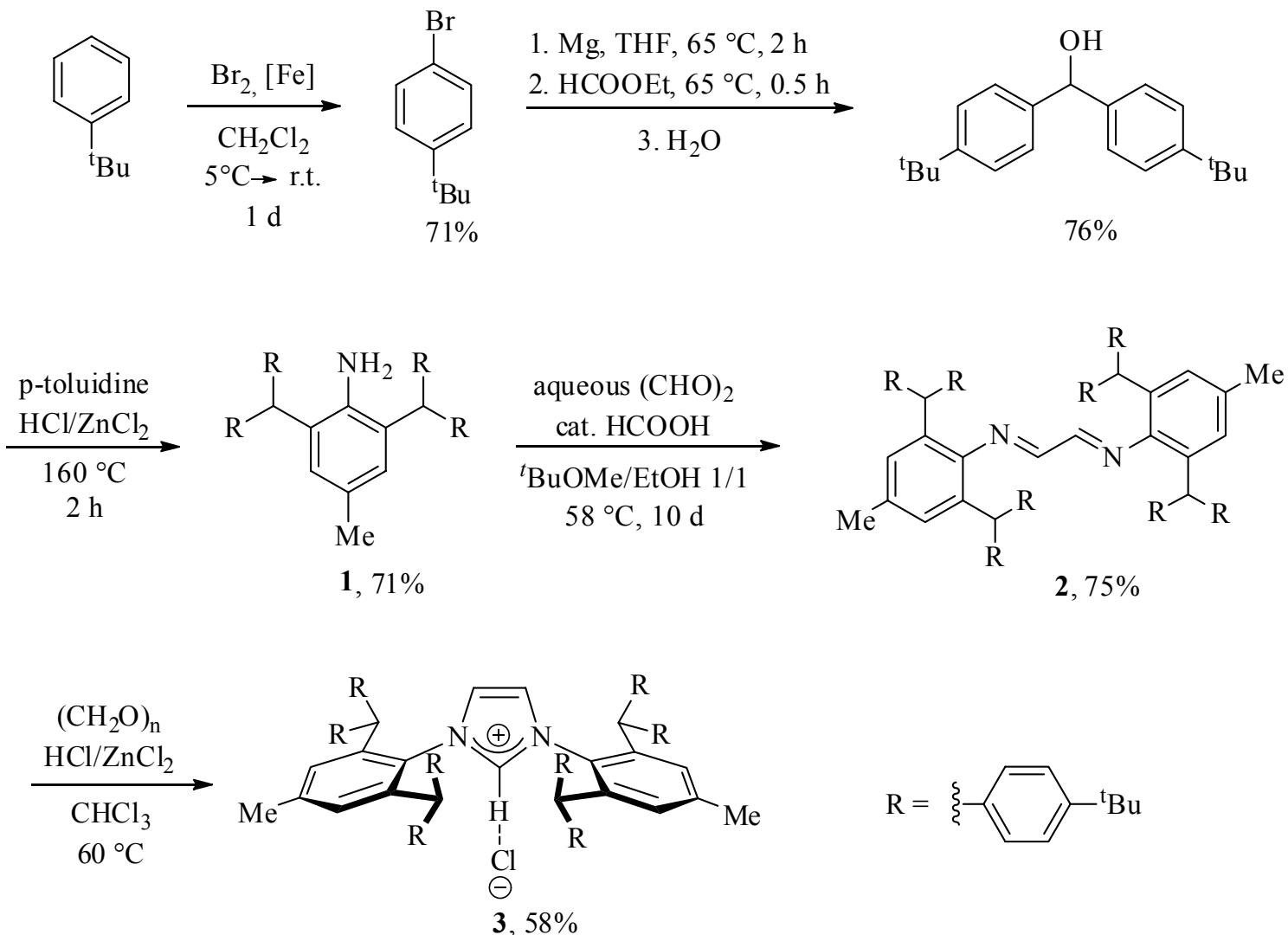

Scheme 1. Synthesis of IPr***HCl (3). 

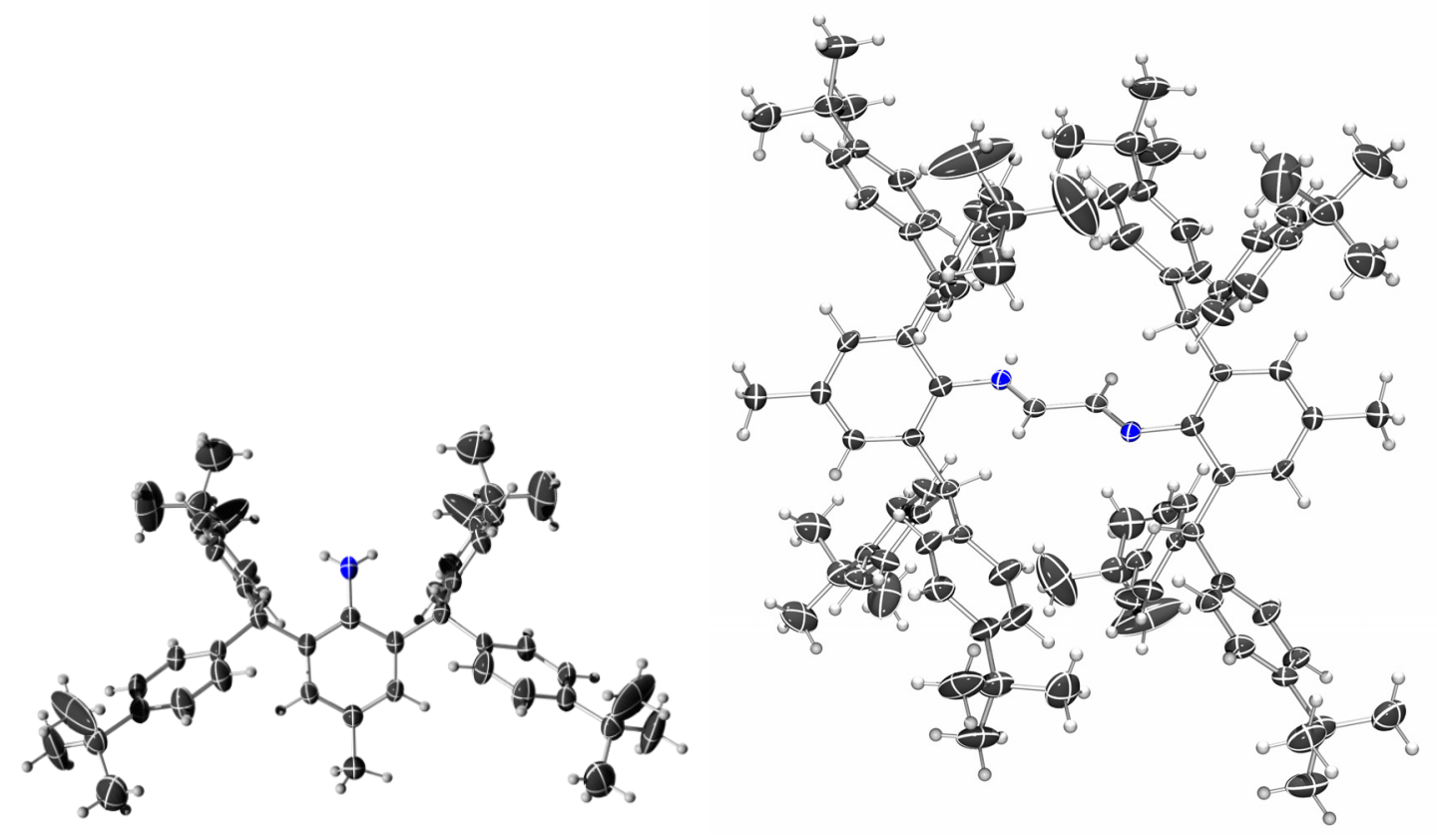

Figure 4. ORTEP plots of the single-crystal X-ray structures of toluidine 1 (left) and diimine 2 (right). The disordered methyl group of the toluidine derivative $\mathbf{1}$ has been simplified. Color code: C black, $\mathrm{H}$ gray, $\mathrm{N}$ blue. ${ }^{19,20}$

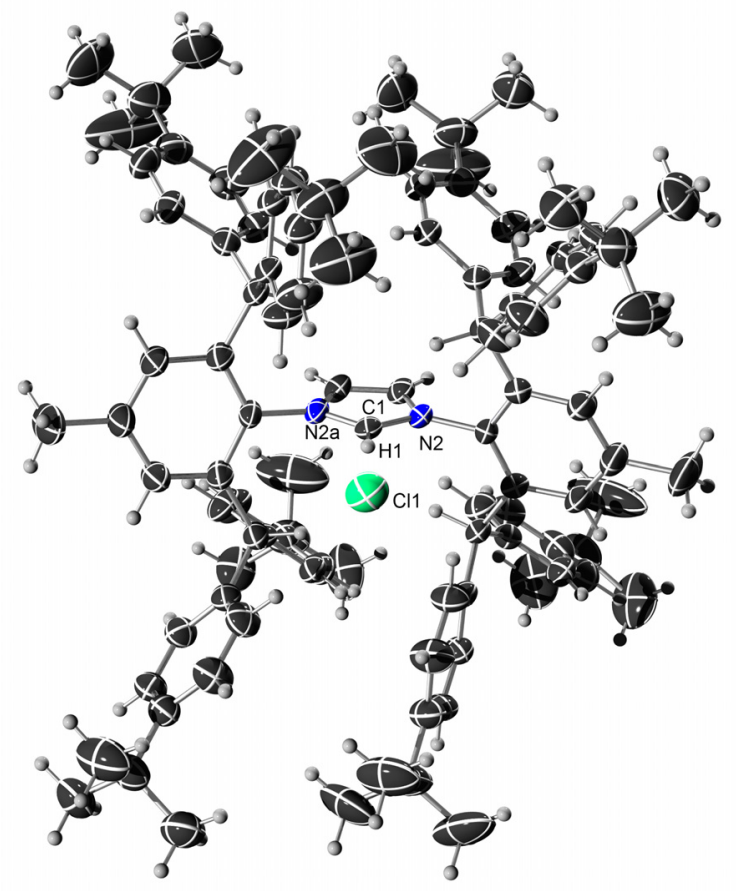

Figure 5. ORTEP plot of the single-crystal X-ray structure of $\mathrm{IPr}^{* *} \cdot \mathrm{HCl}(3)$. Color code: $\mathrm{C}$ black, $\mathrm{H}$ gray, $\mathrm{N}$ blue, $\mathrm{Cl}$ green. Selected angles $\left({ }^{\circ}\right)$ and bond lengths $(\AA)$ : N2a-C1-N2 107.7, C1H1 0.95, H1-C11 2.30. ${ }^{19,20}$ 
The number of signals in the ${ }^{1} \mathrm{H}-\mathrm{NMR}$ spectrum of $\mathrm{IPr} * * \cdot \mathrm{HCl}(3)$ is limited due to its high symmetry (Figure 6), which is $\mathrm{C}_{2 \mathrm{v}}$ on the NMR time scale (Figure 6). The chemical shift of the imidazolium proton of $12.9 \mathrm{ppm}$ is very close to the respective chemical shift in IPr* of 13.0 ppm. ${ }^{14}$ The imidazolium proton of $\operatorname{IPr} \mathrm{HCl}\left(\mathrm{H}_{\mathrm{Im}}=10.0 \mathrm{ppm}, \mathrm{CDCl}_{3}\right)^{13}$ features a highfield shift of nearly $3 \mathrm{ppm}$, presumably due to a less stable hydrogen bond. A dedicated C-H-Cl hydrogen bond is apparent in the single-crystal X-ray structure analysis of IPr**.HCl. The eight tert-butyl groups are divided into two sets of diastereotopic substituents. There is one ${ }^{1} \mathrm{H}$ NMR signal for four tert-butyl groups at the NCHN side of the imidazolium ring, and a second signal for the four tert-butyl groups at the $\mathrm{NCH}=\mathrm{CHN}$ side. Of course, the analogous observation also applies to the aromatic signals of the eight tert-butylphenyl groups.

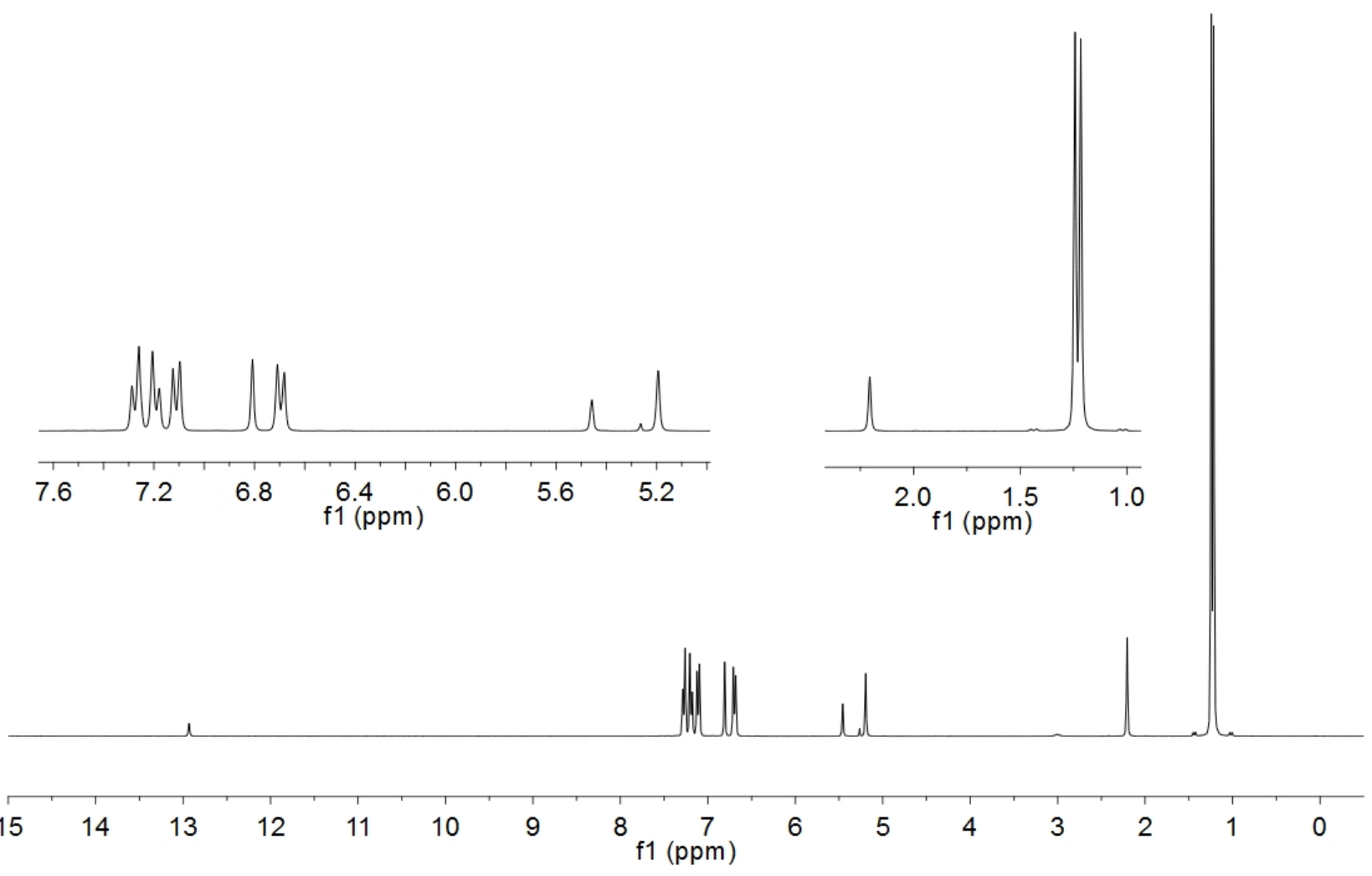

Figure 6. ${ }^{1} \mathrm{H}-\mathrm{NMR}$ spectrum of $\mathrm{IPr}^{* *} \cdot \mathrm{HCl}(3)$ in $\mathrm{CDCl}_{3}$ at $25{ }^{\circ} \mathrm{C}$ and $300 \mathrm{MHz}$.

We here also report the synthesis of the IPr** palladium complex 4. Imidazolium deprotonation and palladium coordination were successfully achieved by a modified literature protocol. $^{21}$ 


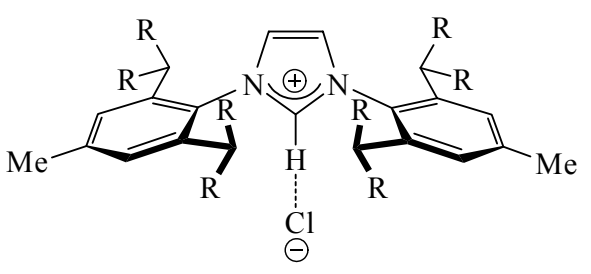

3

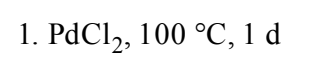

2. $\mathrm{K}_{2} \mathrm{CO}_{3}, 100{ }^{\circ} \mathrm{C}, 5 \mathrm{~d}$ pyridine

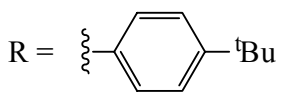

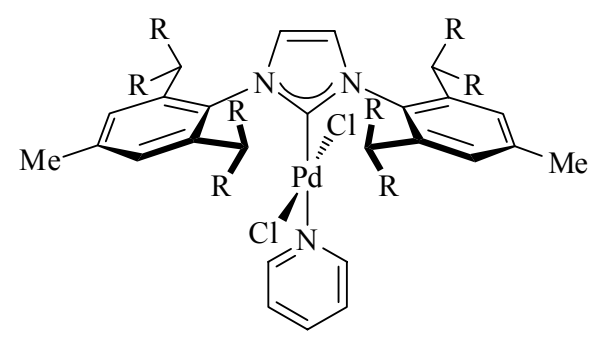

4, $70 \%$

Scheme 2. Synthesis of the palladium complex 4 .

The obtained palladium complex was completely characterized, including a single-crystal Xray analysis.

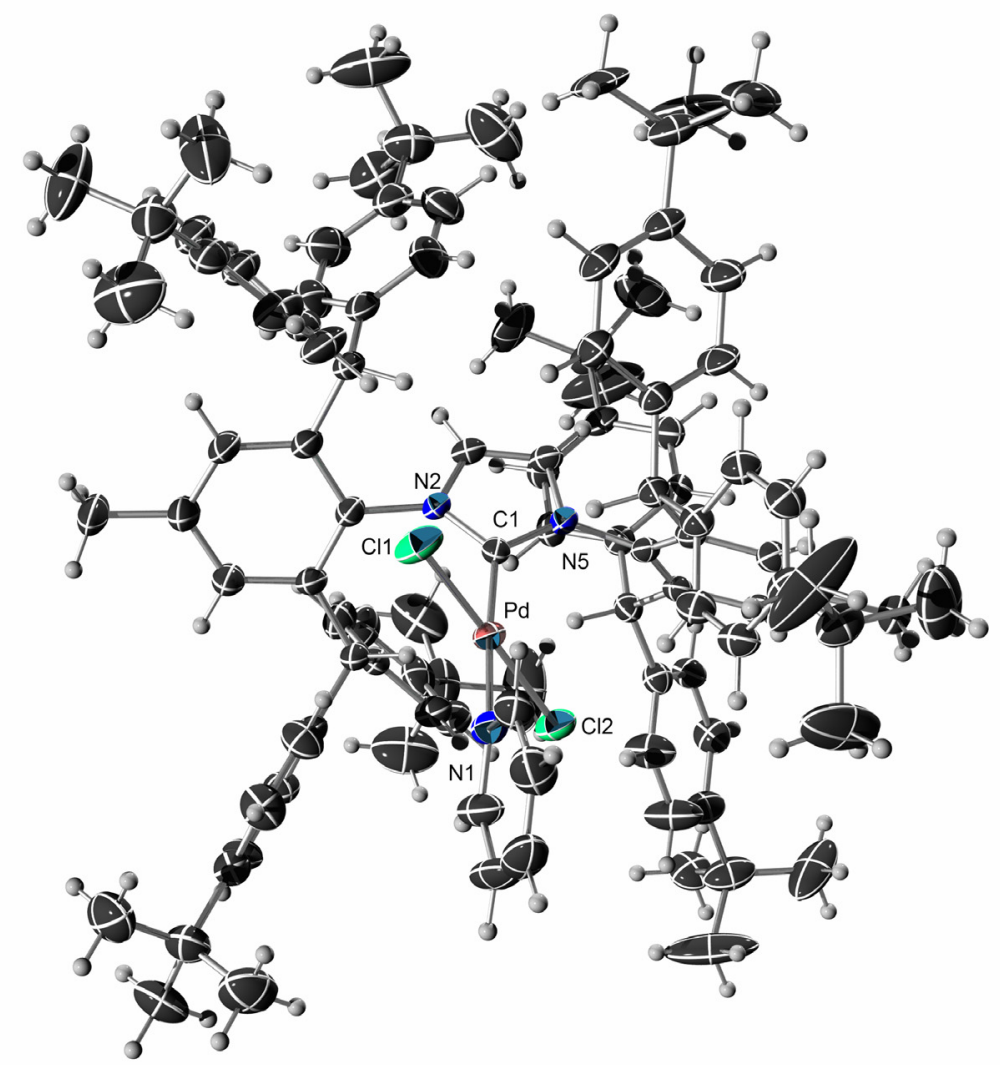

Figure 7. ORTEP plot of the single-crystal X-ray structure of $\left(\operatorname{IPr}^{* *}\right) \operatorname{Pd}(\mathrm{py}) \mathrm{Cl}_{2}$ (4). Color code: $\mathrm{C}$ black, $\mathrm{H}$ gray, $\mathrm{N}$ blue, $\mathrm{Cl}$ green, Pd red. Selected angles $\left(^{\circ}\right)$, bond lengths $(\AA)$ : N2-C1-N5 104.0, C1-Pd 1.97, Pd-N1 2.10. ${ }^{19,20}$

\section{Catalytic applicability}

The complex ( $\left.\mathrm{IPr}^{* *}\right) \mathrm{Pd}(\mathrm{py}) \mathrm{Cl}_{2}$ displays low catalytic activity in the copper-free Sonogashira coupling of phenylacetylene with iodobenzene (Scheme 3). Under standard reaction conditions 
reported in the literature, ${ }^{21}$ an isolated yield of $27 \%$ diphenylacetylene product suggests that the Sonogashira coupling does not benefit from the steric demand of the IPr** system.

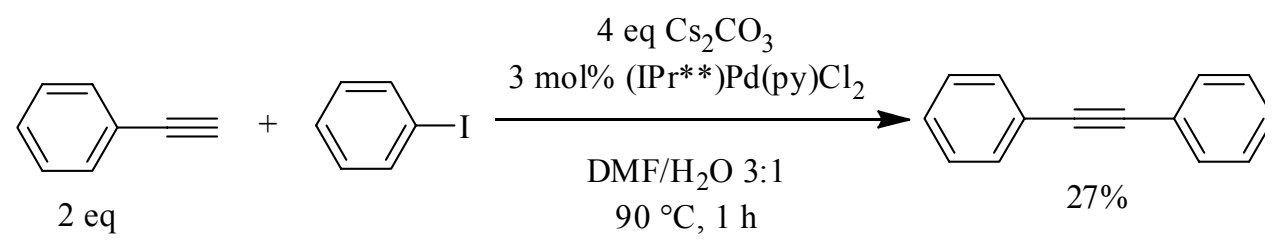

Scheme 3. Copper-free Sonogashira reaction.

No catalytic activity was observed in the Suzuki-Miyaura coupling between paratolylboronic acid and 4-chloroanisole (Scheme 4). ${ }^{22}$ Only traces of the desired product were detected by ${ }^{1}$ H-NMR spectroscopy and EI-MS spectrometry. However, 4,4'-dimethylbiphenyl (2 $\%$ ) was isolated by column chromatography, exactly matching the added amount of palladium(II) complex 4. According to the proposed general catalytic cycle for Pd-PEPPSI-IPr, this homocoupling product originates from the activation of the catalyst. ${ }^{23}$ Formation of a black precipitate was observed, presumably palladium metal.
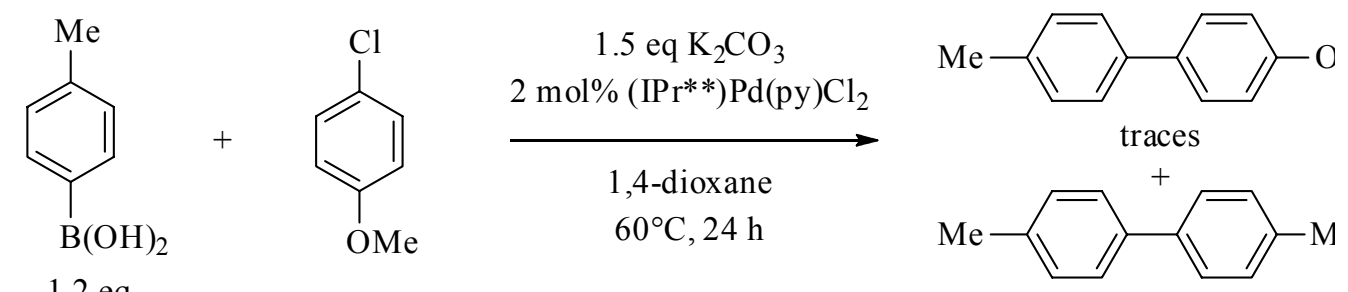

Scheme 4. No catalytic activity in Suzuki-Miyaura cross-coupling.

\section{Discussion of buried volumes}

A buried volume ${ }^{5,24}$ of the X-ray structure (IPr**)Pd(py)Cl $\mathrm{Cl}_{2}$ was determined to $46.2 \%$. The same structure, used as input for a DFT structure optimization, resulted in a buried volume of $44.3 \%$. The BP86/LACVP** level of theory as implemented in the Jaguar program was used. ${ }^{25,26}$ For (IPr)Pd(py) $\mathrm{Cl}_{2}$, also obtained by DFT structure optimization, the corresponding buried volume of $34.1 \%$ was much smaller. However, the computed (IPr*)Pd(py)Cl $\mathrm{Cl}_{2}$ structure leads to a value of $44.6 \%$, indistinguishable to the $\operatorname{IPr}^{* *}$ value within the error margin of the computational approach. Apparently, the tert-butyl groups are too distant from the palladium atom in order to influence its buried volume.

However, the computed structures of (IPr**)AuCl $\left(V_{\text {bur }}=53 \%\right)$ and of $\left(\operatorname{IPr}^{* *}\right) \operatorname{AgCl}\left(V_{\text {bur }}=\right.$ $54.5 \%$ ) feature the highest buried volumes reported so far. As in the palladium complex 4 , experimental values are again expected to be even higher, since the density functionals do not 
reproduce van-der-Waals attractions that favor the proximity of IPr** substituents and the metal fragment.

The buried volume values derived from the ( $\mathrm{NHC}) \mathrm{AgCl}$ complexes are about 3 percentage points higher than the corresponding values of (NHC)AuCl complexes. The $\mathrm{Pd}(\mathrm{py}) \mathrm{Cl}_{2}$ fragment is significantly larger, the substituents of the NHC are pushed away from the metal, thus resulting in low buried volumes. Thus, the following order of buried volume values is derived:

$$
V_{b u r}(\mathrm{NHC}) \mathrm{AgCl}>V_{\text {bur }}(\mathrm{NHC}) \mathrm{AuCl}>>V_{\text {bur }}(\mathrm{NHC}) \mathrm{Pd}(\mathrm{py}) \mathrm{Cl}_{2}
$$

The large difference of IPr**'s buried volumes for different metal fragments indicates a considerable ligand flexibility due to partial rotation of the four substituted benzhydryl groups.

\section{A modified one-dimensional approach for the quantification of steric shielding}

As a modified model, we were interested in the steric shielding of a second ligand in trans position by the bulky ancillary NHC ligand.

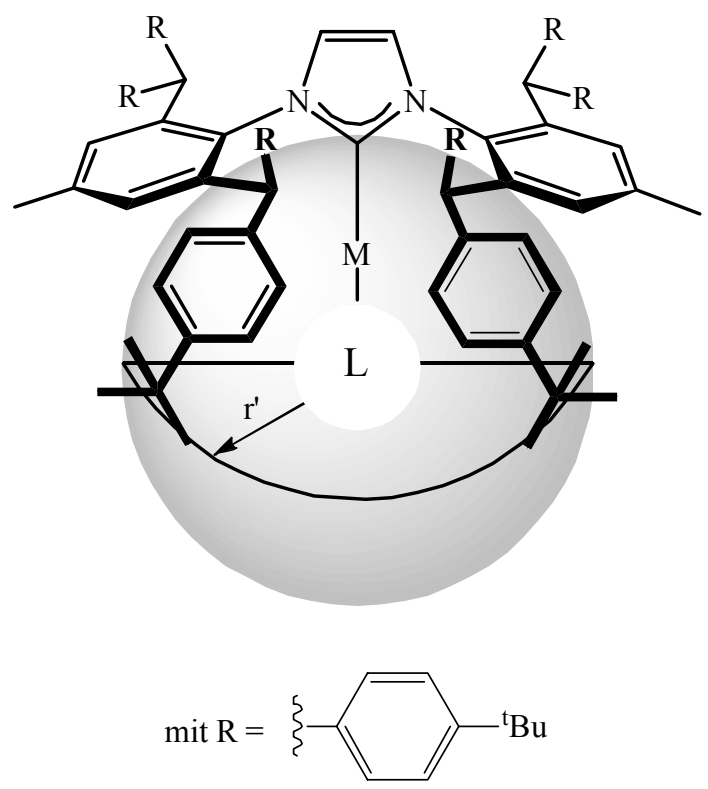

Figure 8. Modified model with the trans ligand L as center of the sphere.

Taking the pyridine's nitrogen ligand atom as center of the sphere (Figure 7), a modified buried volume of $30.9 \%$ was obtained. The addition of tert-butyl groups to the IPr* system does not result in higher buried volume values. Apparently, the tert-butyl groups are located outside of the sphere with the r' radius around the ligand atom. Thus, the IPr** ancillary ligand will provide steric shielding for a second ligand against bulky reactants. 
Table 1. Buried volumes of IPr, IPr* and IPr** complexes ${ }^{5 b, 24}$

\begin{tabular}{cccccccc}
\hline$V_{\text {bur }}$ & {$[\%]$} & $V_{\text {bur }}$ & $\begin{array}{c}\text { XRD } \\
{[\%]}\end{array}$ & $\begin{array}{c}\text { DFT } \\
{[\%]}\end{array}$ & $\begin{array}{c}\text { Second ligand } \\
\text { buried volume }\end{array}$ & $\begin{array}{c}\text { XRD } \\
{[\%]}\end{array}$ & $\begin{array}{c}\text { DFT } \\
{[\%]}\end{array}$ \\
\hline$(\mathrm{IPr}) \mathrm{AuCl}$ & 44.5 & $(\mathrm{IPr}) \mathrm{Pd}(\mathrm{py}) \mathrm{Cl}_{2}$ & - & $34.1^{\mathrm{a}}$ & $(\mathrm{IPr}) \mathrm{Pd}(\mathrm{py}) \mathrm{Cl}_{2}$ & - & $17.2^{\mathrm{a}}$ \\
$(\mathrm{IPr}) \mathrm{AuCl}$ & 50.4 & $(\mathrm{IPr}) \mathrm{Pd}(\mathrm{py}) \mathrm{Cl}_{2}$ & - & $44.6^{\mathrm{a}}$ & $(\mathrm{IPr}) \mathrm{Pd}(\mathrm{py}) \mathrm{Cl}_{2}$ & - & $29.5^{\mathrm{a}}$ \\
$(\mathrm{IPr} * *) \mathrm{AuCl}$ & $53^{\mathrm{a}}(\mathrm{DFT})$ & $(\mathrm{IPr} *) \mathrm{Pd}(\mathrm{py}) \mathrm{Il}_{2}$ & $46.2^{\mathrm{a}}$ & $44.3^{\mathrm{a}}$ & $\left(\mathrm{IPr}^{* *}\right) \mathrm{Pd}(\mathrm{py}) \mathrm{Cl}_{2}$ & $30.9^{\mathrm{a}}$ & $29^{\mathrm{a}}$ \\
\hline
\end{tabular}

a) this work.

\section{A two-dimensional representation for the quantification of steric shielding}

Chemical structures of NHC ligands are defined by the three space dimensions. The concept of buried volume is a one-dimensional approach. We present a less simplifying model that uses two dimensions for the reproduction of steric demand. The quantification of steric shielding of the central atom by the ancillary ligand is based on two parameters:

(1) The distance of an atom X of the NHC ancillary ligand to the metal center.

(2) The angle between the carbene atom, the metal center and the respective atom $\mathrm{X}$ within the NHC ancillary ligand.

For the 3-chloropyridine complex $(\operatorname{IPr}) \mathrm{Pd}\left(3-\mathrm{ClC}_{5} \mathrm{H}_{4} \mathrm{~N}\right) \mathrm{Cl}_{2},{ }^{27}$ steric shielding is defined by maximum $\alpha$ values of $82^{\circ}$ for $\mathrm{X}=$ carbon atoms and $92.5^{\circ}$ for $\mathrm{X}=$ hydrogen atoms (Figure 9). Thus, IPr's steric bulk is concentrated in an area up to $83^{\circ}$ at metal substituent distances between $3 \AA$ and $7 \AA$.

\section{(IPr)Pd(3-chloropyridine) $\mathrm{Cl}_{2}$}

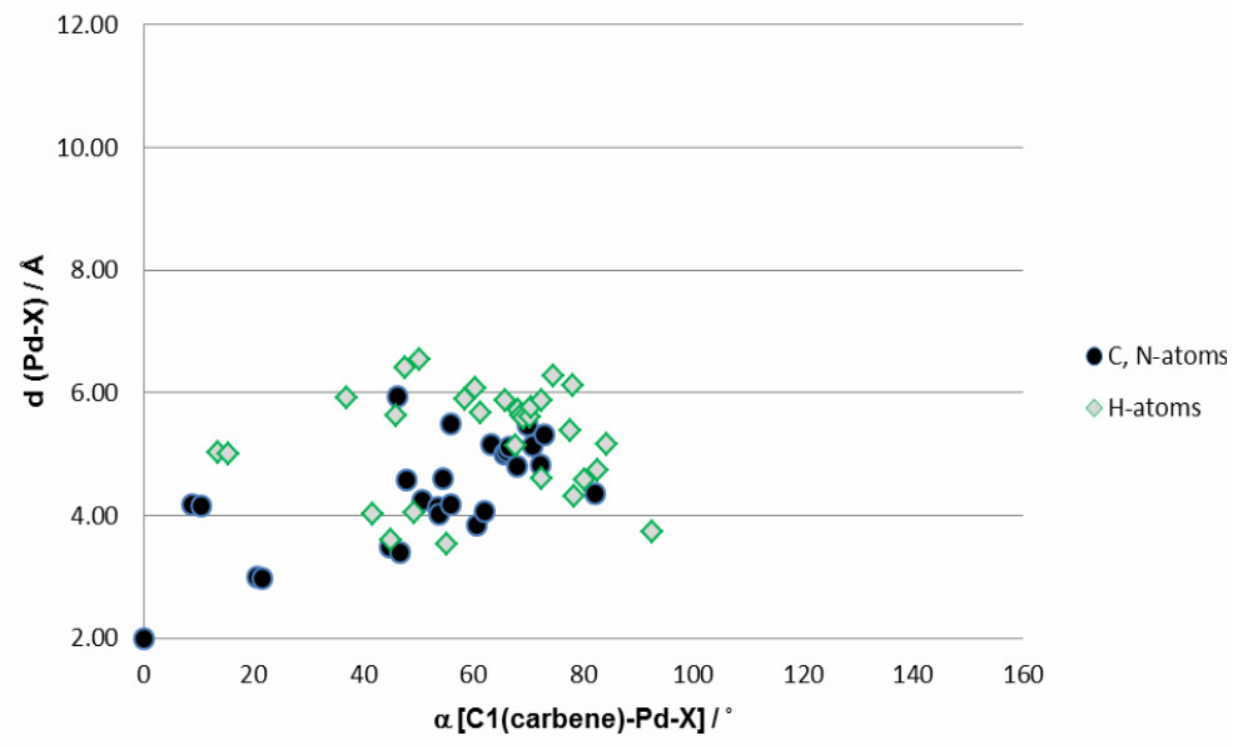

Figure 9. Two dimensional representation of $\mathrm{C}$ (carbene)-Pd-X angles and $\mathrm{Pd}-\mathrm{X}$ distances for (IPr) $\mathrm{Pd}\left(3\right.$-chloropyridine) $\mathrm{Cl}_{2}{ }^{19}$ 
For $\left(\operatorname{IPr}^{* *}\right) \operatorname{Pd}(\mathrm{py}) \mathrm{Cl}_{2}$, only the atoms at the $\mathrm{NCN}$ side of the imidazolylidene have been considered. Figure 10 shows IPr**'s steric shielding up to carbene-palladium-X angles $\alpha$ of $105^{\circ}$ for carbon atoms and $108.6^{\circ}$ for hydrogen atoms at close range $(\mathrm{Pd}-\mathrm{X}$ distance between $2 \AA$ and $4 \AA$ ). At medium range (Pd-X distance between $4 \AA$ to $6 \AA$ ), angles of up to $117.6^{\circ}$ for carbon atoms and $126^{\circ}$ for hydrogen atoms are covered. Without tert-butyl groups, the diagram equals that of the IPr* ligand core. In a more distant Pd-X range ( $>6 \AA)$, the tert-butyl groups result in shielding up to angles of $134^{\circ}$ for $\mathrm{X}$ carbon atoms and $139^{\circ}$ for hydrogen atoms.

While the standard approach to the calculation of buried volumes recovers the additional shielding of IPr** compared to IPr* only for some metal fragments, the two-dimensional approach delivers detailed insight into the steric consequences of the additional substituents.

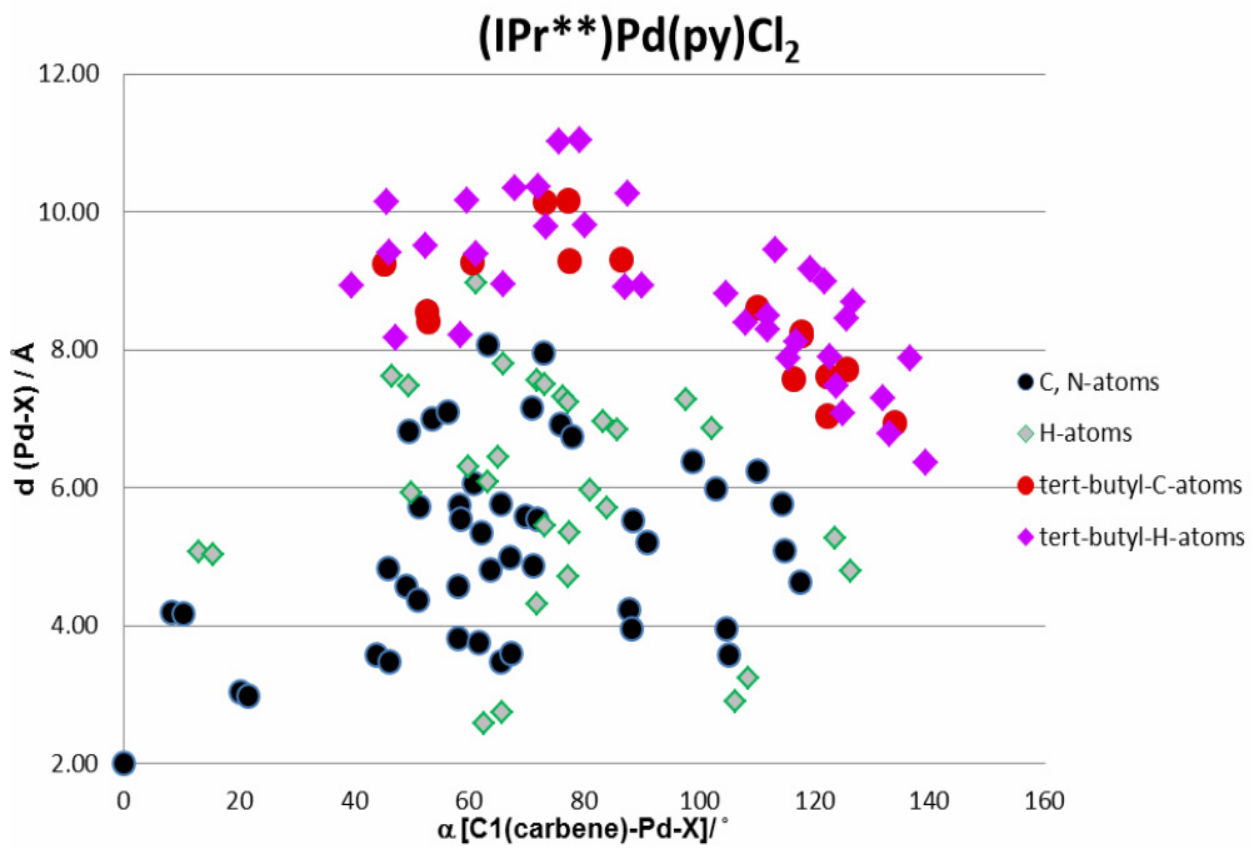

Figure 10. Two dimensional representation of $\mathrm{C}$ (carbene)-Pd-X angles and $\mathrm{Pd}-\mathrm{X}$ distances for $\left(\mathrm{IPr}^{* *}\right) \mathrm{Pd}(\mathrm{py}) \mathrm{Cl}_{2}$

\section{Conclusions}

The N-heterocyclic carbene system IPr** has been prepared and characterized. For the computed $\mathrm{AuCl}$ complex, a new record for steric shielding of late transition metals by an NHC ligand has been established. High solubility in organic solvents, aesthetic NMR spectra, and a high tendency towards crystallization have been demonstrated for the ligand precursor and a derived palladium(II) complex. The complex ( $\left.\mathrm{IPr}^{* *}\right) \mathrm{Pd}(\mathrm{py}) \mathrm{Cl}_{2}$ has low catalytic activity in the Sonogashira reaction and no activity in the Suzuki-Myaura cross-coupling. A two-dimensional representation for the quantification of steric demand of bulky ancillary has been put forward, 
applied, and discussed. The additional steric shielding of the IPr** system will help to reject large substrates that would otherwise react with highly electrophilic or nucleophilic metal fragments. The unique steric demand of $\operatorname{IPr}^{* *}$ establishes an opportunity for the stabilization of reactive metal fragments that are proposed as intermediates in catalytic cycles. Palladium(0) arene complexes and cationic gold(I) carbene complexes are future targets for the detection by NMR spectroscopy, and isolation by crystallization.

\section{Experimental Section}

General. Starting materials as supplied by Acros Organics, Aldrich Chemical and Co., and TCI were used without further purification. Reactions involving air-sensitive reagents were carried out under $\mathrm{N}_{2}$ or argon by using standard Schlenk techniques. Solvents were dried in an Mbraun MB SCS-800 solvent purification system. NMR spectra were recorded at $298 \mathrm{~K}$ by using Bruker ARX-250, Bruker Avance 300, or Bruker Avance 500 spectrometers. Chemical Shifts are reported in ppm relative to TMS, and were determined by reference to the ${ }^{13} \mathrm{C}$ or residual ${ }^{1} \mathrm{H}$ solvent peaks. Melting points were determined by using a Gallenkamp hot-stage microscope.

\section{1-Bromo-4-tert-butylbenzene ${ }^{16,28}$}

Tert-butylbenzene $(134.2 \mathrm{~g}, 1.000 \mathrm{~mol})$ and a small amount of iron powder in a $1 \mathrm{~L}$ round bottom flask was cooled to $5-8^{\circ} \mathrm{C}$. A solution of $\mathrm{Br}_{2}(167.8 \mathrm{~g}, 1.050 \mathrm{~mol})$ in $\mathrm{CH}_{2} \mathrm{Cl}_{2}(50 \mathrm{ml})$ was added dropwise. The resulting mixture was stirred overnight at room temperature. It was then quenched with $1 \mathrm{M}$ aqueous $\mathrm{NaOH}(400 \mathrm{ml})$ and extracted with $\mathrm{CH}_{2} \mathrm{Cl}_{2}(3 \times 130 \mathrm{ml})$. The combined organic layers were washed with $\mathrm{NaHSO}_{3}$ solution $(3 \times 130 \mathrm{ml})$, dried over $\mathrm{MgSO}_{4}$ and concentrated in vacuo. The residue was purified by vacuum distillation (literature: ${ }^{28} 80$ $81^{\circ} \mathrm{C}$ at 2 Torr).

Colorless liquid, yield 71\%, $151.8 \mathrm{~g}$, bp $60{ }^{\circ} \mathrm{C} / 1.5 \mathrm{mbar} ;{ }^{1} \mathrm{H}$ NMR $\left(300.1 \mathrm{MHz}, \mathrm{CDCl}_{3}\right): \delta_{\mathrm{H}} 1.31$ $\left(9 \mathrm{H}, \mathrm{s}, \mathrm{C}\left(\mathrm{CH}_{3}\right)_{3}\right), 7.27\left(2 \mathrm{H}, \mathrm{d},{ }^{3} \mathrm{~J}_{\mathrm{HH}}=8.7 \mathrm{~Hz}, \mathrm{H}_{\mathrm{Ph}}\right), 7.42\left(2 \mathrm{H}, \mathrm{d},{ }^{3} \mathrm{~J}_{\mathrm{HH}}=8.7 \mathrm{~Hz}, \mathrm{H}_{\mathrm{Ph}}\right) .{ }^{13} \mathrm{C} \mathrm{NMR}$ $\left(75.5 \mathrm{MHz}, \mathrm{CDCl}_{3}\right): \delta_{\mathrm{C}} 31.2\left(\mathrm{CH}_{3}\right), 34.5\left(\mathrm{q}-\mathrm{C}\left(\mathrm{CH}_{3}\right)_{3}\right), 119.2(\mathrm{CBr}), 127.2\left(\mathrm{C}_{\mathrm{Ph}}\right), 131.0\left(\mathrm{C}_{\mathrm{Ph}}\right)$, $150.1\left(\mathrm{q}-\mathrm{C}_{\mathrm{Ph}}\right)$. MS (EI), m/z $(\%)=212.0\left(\mathrm{M}^{+}, 100\right)$; Anal. Calcd. for $\mathrm{C}_{10} \mathrm{H}_{13} \mathrm{Br}$ (213.11): C, 56.36; H, 6.15\%. Found: C, 56.31; H, 6.26\%.

\section{Bis(4-tert-butylphenyl)methanol ${ }^{17}$}

A solution of 1-bromo-4-tert-butylbenzene $(50.0 \mathrm{~g}, 0.235 \mathrm{~mol})$ in tetrahydrofuran $(150 \mathrm{ml})$ was added dropwise to magnesium turnings $(7.50 \mathrm{~g}, 0.309 \mathrm{~mol})$ under stirring. After two hours under reflux conditions, the reaction mixture was cooled to room temperature. A solution of ethyl formate $(7.82 \mathrm{~g}, 0.106 \mathrm{~mol})$ in tetrahydrofuran $(12.5 \mathrm{ml})$ was added dropwise. The reaction mixture was heated for another $30 \mathrm{~min}$, cooled to room temperature, quenched with an aqueous $\mathrm{NH}_{4} \mathrm{Cl}$ solution $(250 \mathrm{ml})$ and extracted with $\mathrm{CH}_{2} \mathrm{Cl}_{2}(3 \times 100 \mathrm{ml})$. The combined organic layers 
were dried over $\mathrm{MgSO}_{4}$ and concentrated in vacuo. The crude product was recrystallized from pentane.

Off-white solid, yield $76 \%, 23.9 \mathrm{~g}, \mathrm{mp} 110-111^{\circ} \mathrm{C}$ (literature: $\left.{ }^{29} 103-104^{\circ} \mathrm{C}\right),{ }^{1} \mathrm{H}$ NMR $(300.2$ $\left.\mathrm{MHz}, \mathrm{CDCl}_{3}\right): \delta_{\mathrm{H}} 1.35\left(18 \mathrm{H}, \mathrm{s}, \mathrm{C}\left(\mathrm{CH}_{3}\right)_{3}\right), 2.32(1 \mathrm{H}, \mathrm{s}, \mathrm{OH}), 5.81(1 \mathrm{H}, \mathrm{s}, \mathrm{CHOH}), 7.35(2 \mathrm{H}, \mathrm{d}$, $\left.{ }^{3} \mathrm{~J}_{\mathrm{HH}}=8.6 \mathrm{~Hz}, \mathrm{H}_{\mathrm{Ph}}\right), 7.40\left(2 \mathrm{H}, \mathrm{d},{ }^{3} \mathrm{~J}_{\mathrm{HH}}=8.6 \mathrm{~Hz}, \mathrm{H}_{\mathrm{Ph}}\right) .{ }^{13} \mathrm{C} \mathrm{NMR}\left(75.5 \mathrm{MHz}, \mathrm{CDCl}_{3}\right): \delta_{\mathrm{C}} 31.3$ $\left(\mathrm{CH}_{3}\right), 34.5\left(\mathrm{q}-\mathrm{C}\left(\mathrm{CH}_{3}\right)_{3}\right), 75.8(\mathrm{COH}), 125.3\left(\mathrm{C}_{\mathrm{Ph}}\right), 126.2\left(\mathrm{C}_{\mathrm{Ph}}\right), 141.0\left(\mathrm{q}-\mathrm{C}_{\mathrm{Ph}}\right), 150.3\left(\mathrm{q}-\mathrm{C}_{\mathrm{Ph}}\right) ; \mathrm{MS}$ $(\mathrm{ESI}), \mathrm{m} / \mathrm{z}(\%)=279.3\left([\mathrm{M}-\mathrm{OH}]^{+}, 100\right)$. HR-MS (EI), m/z (\%) for $\mathrm{C}_{21} \mathrm{H}_{28} \mathrm{O}^{+}$: calcd. 296.2140, found 296.2159; Anal. Calcd. for $\mathrm{C}_{21} \mathrm{H}_{20} \mathrm{O}$ (296.45): C, 85.08; H, 9.52\%. Found: C, 84.81; $\mathrm{H}$, $9.60 \%$.

2,6-Bis[bis(4-tert-butylphenyl)methyl]-4-methylaniline (1). Bis(4-tert-butylphenyl)methanol $(3.0 \mathrm{~g}, 10 \mathrm{mmol})$ and $p$-toluidine $(0.54 \mathrm{~g}, 5.1 \mathrm{mmol})$ were melted at $160{ }^{\circ} \mathrm{C}$. A solution of anhydrous $\mathrm{ZnCl}_{2}(0.35 \mathrm{~g}, 2.5 \mathrm{mmol})$ in $36 \%$ aqueous $\mathrm{HCl}(0.42 \mathrm{ml}, 5.1 \mathrm{mmol})$ was added dropwise. The resulting mixture was kept at $160{ }^{\circ} \mathrm{C}$ for $2 \mathrm{~h}$. Once cooled to room temperature, the solid was dissolved in $\mathrm{CH}_{2} \mathrm{Cl}_{2}(40 \mathrm{ml})$ and washed with aqueous $\mathrm{NH}_{4} \mathrm{Cl}$ solution $(3 \times 30 \mathrm{ml})$ and brine $(3 \times 30 \mathrm{ml})$. After drying over anhydrous $\mathrm{K}_{2} \mathrm{CO}_{3}$, silica gel $(10 \mathrm{~g})$ was added to the solution, the mixture was filtered, and concentrated in vacuo. The crude product was stirred in methanol for three days at room temperature, thereby dissolving impurities.

Compound 1. Colorless solid, yield 71\%, $2.4 \mathrm{~g}$, mp 204-205 ${ }^{\circ} \mathrm{C}$; IR (KBr, cm ${ }^{-1}$ ): 3431 (br), 3055 (w), 3025 (w), 2963 (s), 2904 (m), 2867 (m), 1626 (m), 1510 (s), 1466 (s), 1408 (w), 1394 (w), $1363(\mathrm{~m}), 1269(\mathrm{~m}), 830(\mathrm{~m}) .{ }^{1} \mathrm{H}$ NMR $\left(300.1 \mathrm{MHz}, \mathrm{CDCl}_{3}\right): \delta_{\mathrm{H}} 1.30\left(36 \mathrm{H}, \mathrm{s}, \mathrm{C}\left(\mathrm{CH}_{3}\right)_{3}\right), 2.05$ $\left(3 \mathrm{H}, \mathrm{s}, \mathrm{CH}_{3}\right), 5.43\left(2 \mathrm{H}, \mathrm{s}, \mathrm{CHPh}_{2}\right), 6.42\left(2 \mathrm{H}, \mathrm{s}, \mathrm{H}_{\mathrm{Ph}}\right), 7.01\left(8 \mathrm{H}, \mathrm{d},{ }^{3} \mathrm{~J}_{\mathrm{HH}}=8.4 \mathrm{~Hz}, \mathrm{H}_{\mathrm{Ph}}\right), 7.27(8 \mathrm{H}$,

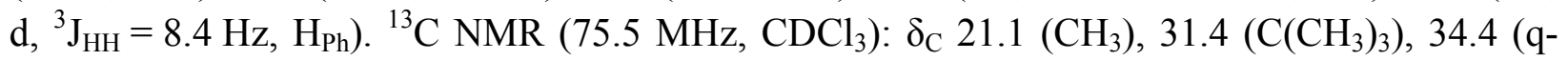
$\left.\mathrm{C}\left(\mathrm{CH}_{3}\right)_{3}\right), 51.4\left(\mathrm{CHPh}_{2}\right), 125.2\left(\mathrm{C}_{\mathrm{Ph}}\right), 126.6\left(\mathrm{q}-\mathrm{C}_{\mathrm{Ph}}\right), 128.8\left(\mathrm{C}_{\mathrm{Ph}}\right), 129.1\left(\mathrm{C}_{\mathrm{Ph}}\right), 129.8\left(\mathrm{q}-\mathrm{C}_{\mathrm{Ph}}\right)$, $139.6\left(\mathrm{q}-\mathrm{C}_{\mathrm{Ph}}\right), 139.8$. (q-C $\left.\mathrm{CPh}_{\mathrm{Ph}}\right), 149.0\left(\mathrm{q}-\mathrm{C}_{\mathrm{Ph}}\right)$; $\mathrm{MS}(\mathrm{EI}), \mathrm{m} / \mathrm{z}(\%)=663.5\left(\mathrm{M}^{+}, 100\right)$. HR-MS (EI), $\mathrm{m} / \mathrm{z}(\%)$ for $\mathrm{C}_{49} \mathrm{H}_{62} \mathrm{~N}^{+}$: calcd. 664.4877, found 664.4877; Anal. Calcd. for $\mathrm{C}_{49} \mathrm{H}_{61} \mathrm{~N}$ (664.02): C, 88.63; H, 9.26; N, 2.11\%. Found: C, 88.56; H, 9.34; N, 2.04\%. CCDC 857249

$N, N^{\prime}$-Bis[2,6-bis[bis(4-tert-butylphenyl)methyl]-4-methylphenyl]-1,4-diazabutadiene (2). To a solution of 2,6-Bis[bis(4-tert-butylphenyl)methyl]-4-methylaniline 1 (11.5 g, $17.0 \mathrm{mmol})$ in methyl tert-butyl ether $(250 \mathrm{ml})$ and ethanol $(250 \mathrm{ml})$ was added glyoxal $(1.0 \mathrm{ml}, 22.0 \mathrm{mmol}$, $40 \%$ aq. solution) and a catalytic amount of formic acid. The mixture was stirred at $58{ }^{\circ} \mathrm{C}$ for 10 d. The yellow precipitate was then filtered, washed with ethanol and dried in vacuo.

Compound 2. Yellow solid, yield 75\%, $8.7 \mathrm{~g}, \mathrm{mp}>330{ }^{\circ} \mathrm{C}$; IR $\left(\mathrm{KBr}, \mathrm{cm}^{-1}\right): 3053(\mathrm{w}), 3026(\mathrm{w})$, 2963 (s), 2904 (m), 2867 (m), 1629 (m), 1511 (s), 1475 (m), 1461 (m), 1409 (w), 1393 (w), 1363 (m), $1269(\mathrm{~m}), 1202(\mathrm{~m}), 1110(\mathrm{~m}), 842(\mathrm{~m}), 831(\mathrm{~m}) ;{ }^{1} \mathrm{H}$ NMR $\left(300.1 \mathrm{MHz}, \mathrm{CDCl}_{3}\right): \delta_{\mathrm{H}} 1.24$ $\left(72 \mathrm{H}, \mathrm{s}, \mathrm{C}\left(\mathrm{CH}_{3}\right)_{3}\right), 2.17\left(6 \mathrm{H}, \mathrm{s}, \mathrm{CH}_{3}\right), 5.30\left(4 \mathrm{H}, \mathrm{s}, \mathrm{CHPh}_{2}\right), 6.78\left(4 \mathrm{H}, \mathrm{s}, \mathrm{H}_{\mathrm{Ph}}\right), 6.93(16 \mathrm{H}, \mathrm{d}$, $\left.{ }^{3} \mathrm{~J}_{\mathrm{HH}}=8.4 \mathrm{~Hz}, \mathrm{H}_{\mathrm{Ph}}\right), 7.19\left(16 \mathrm{H}, \mathrm{d},{ }^{3} \mathrm{~J}_{\mathrm{HH}}=8.4 \mathrm{~Hz}, \mathrm{H}_{\mathrm{Ph}}\right), 7.44(2 \mathrm{H}, \mathrm{s}, \mathrm{NCH}=\mathrm{CHN}) .{ }^{13} \mathrm{C} \mathrm{NMR}(75.5$

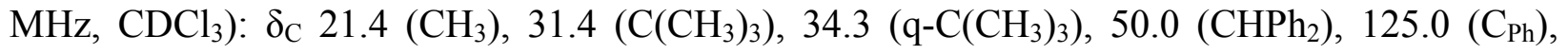
$128.9\left(\mathrm{C}_{\mathrm{Ph}}\right), 129.0\left(\mathrm{C}_{\mathrm{Ph}}\right), 132.3\left(\mathrm{q}-\mathrm{C}_{\mathrm{Ph}}\right), 133.3\left(\mathrm{q}-\mathrm{C}_{\mathrm{Ph}}\right), 140.8\left(\mathrm{q}-\mathrm{C}_{\mathrm{Ph}}\right), 146.9\left(\mathrm{q}-\mathrm{C}_{\mathrm{Ph}}\right), 148.7(\mathrm{q}-$ 
$\left.\mathrm{C}_{\mathrm{Ph}}\right), 164.3(\mathrm{NCH}=\mathrm{CHN}) ; \mathrm{MS}(\mathrm{ESI}), \mathrm{m} / \mathrm{z}(\%)=1351.0\left([\mathrm{M}+\mathrm{H}]^{+}, 100\right) . \mathrm{HR}-\mathrm{MS}(\mathrm{ESI}), \mathrm{m} / \mathrm{z}(\%)$ for $\mathrm{C}_{100} \mathrm{H}_{121} \mathrm{~N}^{+}$: calcd. 1349.9534, found 1349.9538; Anal. Calcd. for $\mathrm{C}_{100} \mathrm{H}_{120} \mathrm{~N}_{2}$ (1350.04): C, 88.97; H, 8.96; N, 2.08\%. Found: C, 88.81; H, 9.04; N, 2.17\%. CCDC 857250

\section{1,3-Bis[2,6-bis[bis(4-tert-butylphenyl)methyl]-4-methylphenyl]-1H-imidazol-3-ium chloride} (3). To a solution of diimine $2(6.0 \mathrm{~g}, 4.4 \mathrm{mmol})$ in chloroform $(250 \mathrm{ml})$ at $60{ }^{\circ} \mathrm{C}$ was added dropwise a solution of $\left(\mathrm{CH}_{2} \mathrm{O}\right)_{\mathrm{n}}(0.16 \mathrm{~g}, 5.3 \mathrm{mmol})$ and $\mathrm{ZnCl}_{2}(0.73 \mathrm{~g}, 5.3 \mathrm{mmol})$ in $\mathrm{HCl}(36 \%$, $0.9 \mathrm{ml}, 29.6 \mathrm{mmol})$. The color of the reaction mixture turned red. The reaction was stirred overnight at $60{ }^{\circ} \mathrm{C}$. The orange solution was cooled, diluted with $\mathrm{CH}_{2} \mathrm{Cl}_{2}(200 \mathrm{ml})$ and washed with $2 \mathrm{M} \mathrm{HCl}(3 \times 200 \mathrm{ml})$, brine $(3 \times 150 \mathrm{ml})$ and brine of $\mathrm{pH} 8(3 \times 150 \mathrm{ml})$, and dried with anhydrous $\mathrm{MgSO}_{4}$. The solvent was removed in vacuo. The brown residue was recrystallized from $\mathrm{CH}_{2} \mathrm{Cl}_{2} /$ pentane.

Compound 3. Colorless solid, yield 58\%, $3.6 \mathrm{~g}, \mathrm{mp}>330^{\circ} \mathrm{C}$; IR $\left(\mathrm{KBr}, \mathrm{cm}^{-1}\right): 3050(\mathrm{w}), 3028$ (w), 2964 (s), 2904 (m), 2868 (m), 1625 (m), 1605 (m), 1511 (s), 1462 (m), 1408 (w), 1394 (w), $1364(\mathrm{~m}), 1269(\mathrm{~m}), 1110(\mathrm{~m}), 841(\mathrm{~m}), 831(\mathrm{~m}) ;{ }^{1} \mathrm{H}$ NMR $\left(250.1 \mathrm{MHz}, \mathrm{CDCl}_{3}\right): \delta_{\mathrm{H}} 1.22(36 \mathrm{H}$, $\left.\mathrm{s}, \mathrm{C}\left(\mathrm{CH}_{3}\right)_{3}\right), 1.24\left(36 \mathrm{H}, \mathrm{s}, \mathrm{C}\left(\mathrm{CH}_{3}\right)_{3}\right), 2.21\left(6 \mathrm{H}, \mathrm{s}, \mathrm{CH}_{3}\right), 5.19\left(4 \mathrm{H}, \mathrm{s}, \mathrm{CHPh}_{2}\right), 5.46(2 \mathrm{H}, \mathrm{s}$, $\mathrm{NCH}=\mathrm{CHN}), 6.70\left(8 \mathrm{H}, \mathrm{d},{ }^{3} \mathrm{~J}_{\mathrm{HH}}=8.0 \mathrm{~Hz}, \mathrm{H}_{\mathrm{Ph}}\right), 6.81\left(4 \mathrm{H}, \mathrm{s}, \mathrm{H}_{\mathrm{Ph}}\right), 7.11\left(8 \mathrm{H}, \mathrm{d},{ }^{3} \mathrm{~J}_{\mathrm{HH}}=8.0 \mathrm{~Hz}\right.$, $\left.\mathrm{H}_{\mathrm{Ph}}\right), 7.19\left(8 \mathrm{H}, \mathrm{d},{ }^{3} \mathrm{~J}_{\mathrm{HH}}=8.0 \mathrm{~Hz}, \mathrm{H}_{\mathrm{Ph}}\right), 7.27\left(8 \mathrm{H}, \mathrm{d},{ }^{3} \mathrm{~J}_{\mathrm{HH}}=8.0 \mathrm{~Hz}, \mathrm{H}_{\mathrm{Ph}}\right), 12.93(1 \mathrm{H}, \mathrm{s}, \mathrm{NCHN})$.

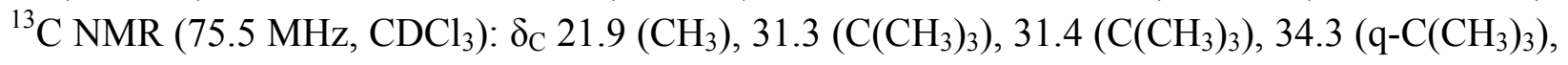
$34.4\left(\mathrm{q}-\mathrm{C}\left(\mathrm{CH}_{3}\right)_{3}\right), 50.5\left(\mathrm{CHPh}_{2}\right), 123.1(\mathrm{NCH}=\mathrm{CHN}), 125.1\left(\mathrm{C}_{\mathrm{Ph}}\right), 125.4\left(\mathrm{C}_{\mathrm{Ph}}\right), 128.6\left(\mathrm{C}_{\mathrm{Ph}}\right)$, $129.6\left(\mathrm{C}_{\mathrm{Ph}}\right), 129.8\left(\mathrm{q}-\mathrm{C}_{\mathrm{Ph}}\right), 130.4\left(\mathrm{C}_{\mathrm{Ph}}\right), 139.0\left(\mathrm{q}-\mathrm{C}_{\mathrm{Ph}}\right), 139.6\left(\mathrm{q}-\mathrm{C}_{\mathrm{Ph}}\right), 140.9 .\left(\mathrm{q}-\mathrm{C}_{\mathrm{Ph}}\right), 141.1$ (q$\left.\mathrm{C}_{\mathrm{Ph}}\right), 149.3\left(\mathrm{q}-\mathrm{C}_{\mathrm{Ph}}\right), 149.5\left(\mathrm{q}-\mathrm{C}_{\mathrm{Ph}}\right), 164.3(\mathrm{NCHN}) ; \mathrm{MS}(\mathrm{ESI}), \mathrm{m} / \mathrm{z}(\%)=1363.0\left([\mathrm{M}-\mathrm{Cl}]^{+}, 100\right)$. HR-MS (ESI), m/z (\%) for $\mathrm{C}_{101} \mathrm{H}_{121} \mathrm{~N}_{2}{ }^{+}$: calcd. 1361.9524, found 1361.9522; Anal. Calcd. for $\mathrm{C}_{101} \mathrm{H}_{121} \mathrm{ClN}_{2}$ (1398.51): C, 86.74; H, 8.72; N, 2.00\%; Calcd. for hydrate $\mathrm{C}_{101} \mathrm{H}_{123} \mathrm{ClN}_{2} \mathrm{O}$ (1416.52): C, 85.64; H, 8.75; N, 2.00. Found: C, 85.24; H, 8.99; N, 1.97\%. CCDC 857251

\section{trans-Palladium[1,3-bis[2,6-bis[bis(4-tert-butylphenyl)methyl]-4-methylphenyl]-1H-imi-}

dazol-2-yliden]( ${ }^{1} \mathbf{N}$-pyridine) dichloride (4). To a solution of imidazolium chloride $\mathbf{3}$ (1.0 g, $0.70 \mathrm{mmol})$ in pyridine $(25 \mathrm{ml})$ was added palladium(II)chloride $(0.2 \mathrm{~g}, 1.2 \mathrm{mmol})$. The reaction mixture was heated to $100{ }^{\circ} \mathrm{C}$ for one day, then potassium carbonate $(0.5 \mathrm{~g}, 3.6 \mathrm{mmol})$ was added. The mixture was heated to $100^{\circ} \mathrm{C}$ for five days. The brown suspension was cooled, filtered over a pad of Celite and diluted with $\mathrm{CH}_{2} \mathrm{Cl}_{2}(50 \mathrm{ml})$. The solvents were removed in vacuo. The resulting orange-brown solid was dissolved in $\mathrm{CH}_{2} \mathrm{Cl}_{2}$ and the solvent was removed in vacuo. This procedure was repeated several times. The beige residue was recrystallized from $\mathrm{CH}_{2} \mathrm{Cl}_{2}$ /pentane.

Compound 4. Off-white solid, yield $70 \%, 0.8 \mathrm{~g}, \mathrm{mp} 271^{\circ} \mathrm{C}$ (decomposition); IR ( $\left.\mathrm{KBr}, \mathrm{cm}^{-1}\right)$ : 3437 (b), 2964 (s), 2904 (m), 2867 (m), 1605 (m), 1511 (s), 1486 (m), 1461 (m), 1449 (w), 1410 (m), 1394 (w), 1363 (m), 1269 (m), 1109 (m), 1020 (m), 841 (s), 806 (w), 694 (m), 652 (w), 576 (m); ${ }^{1} \mathrm{H}$ NMR $\left(300.5 \mathrm{MHz}, \mathrm{CDCl}_{3}\right): \delta_{\mathrm{H}} 1.16\left(36 \mathrm{H}, \mathrm{s}, \mathrm{C}\left(\mathrm{CH}_{3}\right)_{3}\right), 1.28\left(36 \mathrm{H}, \mathrm{s}, \mathrm{C}\left(\mathrm{CH}_{3}\right)_{3}\right), 2.20(6 \mathrm{H}$, $\left.\mathrm{s}, \mathrm{CH}_{3}\right), 4.57(2 \mathrm{H}, \mathrm{s}, \mathrm{NCH}=\mathrm{CHN}), 6.21\left(4 \mathrm{H}, \mathrm{s}, \mathrm{CHPh}_{2}\right), 6.62\left(8 \mathrm{H}, \mathrm{d},{ }^{3} \mathrm{~J}_{\mathrm{HH}}=8.3 \mathrm{~Hz}, \mathrm{H}_{\mathrm{Ph}}\right), 6.77$ 
$\left(4 \mathrm{H}, \mathrm{s}, \mathrm{H}_{\mathrm{Ph}}\right), 6.96\left(8 \mathrm{H}, \mathrm{d},{ }^{3} \mathrm{~J}_{\mathrm{HH}}=8.3 \mathrm{~Hz}, \mathrm{H}_{\mathrm{Ph}}\right), 7.20\left(8 \mathrm{H}, \mathrm{d},{ }^{3} \mathrm{~J}_{\mathrm{HH}}=8.3 \mathrm{~Hz}, \mathrm{H}_{\mathrm{Ph}}\right), 7.30\left(2 \mathrm{H}, \mathrm{m}, \mathrm{H}_{\mathrm{py}}\right)$, $7.35\left(8 \mathrm{H}, \mathrm{d},{ }^{3} \mathrm{~J}_{\mathrm{HH}}=8.3 \mathrm{~Hz}, \mathrm{H}_{\mathrm{Ph}}\right), 7.76\left(1 \mathrm{H}, \mathrm{dt},{ }^{3} \mathrm{~J}_{\mathrm{HH}}=7.8 \mathrm{~Hz},{ }^{4} \mathrm{~J}_{\mathrm{HH}}=1.4 \mathrm{~Hz}, \mathrm{H}_{\mathrm{py}}\right), 9.04(2 \mathrm{H}, \mathrm{dd}$,

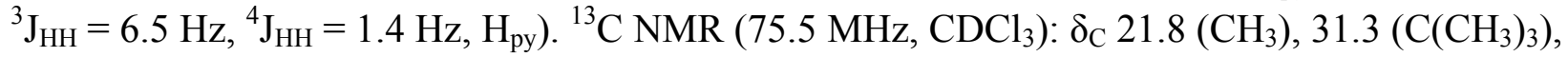

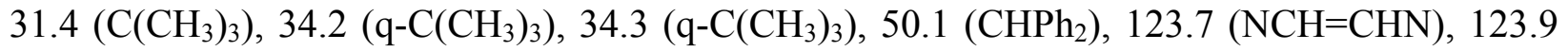
$\left(\mathrm{C}_{\mathrm{py}}\right), 124.5\left(\mathrm{C}_{\mathrm{Ph}}\right), 124.5\left(\mathrm{C}_{\mathrm{Ph}}\right), 129.2\left(\mathrm{C}_{\mathrm{Ph}}\right), 130.0\left(\mathrm{C}_{\mathrm{Ph}}\right), 130.3\left(\mathrm{C}_{\mathrm{Ph}}\right), 135.4\left(\mathrm{q}-\mathrm{C}_{\mathrm{Ph}}\right), 137.6\left(\mathrm{C}_{\mathrm{py}}\right)$, $137.7\left(\mathrm{q}-\mathrm{C}_{\mathrm{Ph}}\right), 141.2\left(\mathrm{q}-\mathrm{C}_{\mathrm{Ph}}\right), 141.5\left(\mathrm{q}-\mathrm{C}_{\mathrm{Ph}}\right), 142.4\left(\mathrm{q}-\mathrm{C}_{\mathrm{Ph}}\right), 148.2\left(\mathrm{q}-\mathrm{C}_{\mathrm{Ph}}\right), 148.5\left(\mathrm{q}-\mathrm{C}_{\mathrm{Ph}}\right), 150.3$ $\left(\mathrm{N}_{2} \mathrm{CPd}\right), 152.1\left(\mathrm{C}_{\mathrm{py}}\right)$; $\mathrm{MS}(\mathrm{FAB}), \mathrm{m} / \mathrm{z}(\%)=1503.6\left(\left[\mathrm{M}-\mathrm{C}_{5} \mathrm{H}_{5} \mathrm{Cl}\right]^{+}, 50\right)$. Anal. Calcd. for $\mathrm{C}_{106} \mathrm{H}_{125} \mathrm{Cl}_{2} \mathrm{~N}_{3} \mathrm{Pd}$ (1618.47): C, 78.66; H, 7.78; N, 2.60. Found: C, 78.40; H, 8.08; N, 2.63\%. CCDC 857252.

\section{Copper-free Sonogashira cross-coupling ${ }^{21}$}

$\mathrm{Cs}_{2} \mathrm{CO}_{3}$ (0.652 g, $\left.2.0 \mathrm{mmol}\right)$, (IPr**)Pd(py)Cl 4 (0.024 g, $0.015 \mathrm{mmol}, 3 \mathrm{~mol} \%$ ), iodobenzene $(55 \mu \mathrm{l}, 0.49 \mathrm{mmol})$ and phenylacetylene $(100 \mu \mathrm{l}, 0.98 \mathrm{mmol})$ were stirred in $\mathrm{DMF} / \mathrm{H}_{2} \mathrm{O} 3: 1$ $(10 \mathrm{ml})$ at $90^{\circ} \mathrm{C}$ for $1 \mathrm{~h}$. The mixture was filtered, and concentrated in vacuo. The crude product was purified via silica gel flash chromatography $\left(\mathrm{PE}, \mathrm{R}_{\mathrm{f}}=0.24\right)$.

Diphenylacetylene. Colorless solid, yield 27\%, $24 \mathrm{mg} ;{ }^{1} \mathrm{H} \mathrm{NMR}\left(300.5 \mathrm{MHz}, \mathrm{CDCl}_{3}\right): \delta_{\mathrm{H}} 7.35$ $7.37\left(6 \mathrm{H}, \mathrm{m}, \mathrm{H}_{\mathrm{Ph}}\right), 7.53-7.57\left(4 \mathrm{H}, \mathrm{m}, \mathrm{H}_{\mathrm{Ph}}\right) .{ }^{13} \mathrm{C} \mathrm{NMR}\left(75.6 \mathrm{MHz}, \mathrm{CDCl}_{3}\right): \delta_{\mathrm{C}} 89.4(\mathrm{PhC} \equiv), 123.3$ $\left(\mathrm{q}-\mathrm{C}_{\mathrm{Ph}}\right), 128.2\left(\mathrm{C}_{\mathrm{Ph}}\right), 128.4\left(\mathrm{C}_{\mathrm{Ph}}\right), 131.6\left(\mathrm{C}_{\mathrm{Ph}}\right) ; \mathrm{MS}(\mathrm{EI}), \mathrm{m} / \mathrm{z}(\%)=178.1\left(\mathrm{M}^{+}, 100\right)$.

\section{Acknowledgements}

We thank Dr. Berthon-Gelloz for inspiring discussions. Financial support by the University of Heidelberg, and a fellowship for S. G. W. from its Graduate Academy is gratefully acknowledged.

\section{References and Notes}

1. (a) Scott, N. M.; Nolan, S. P. Eur. J. Inorg. Chem. 2005, 1815. (b) Kantchev, E. A. B.; O’Brien, C. J.; Organ, M. G. Angew. Chem. Int. Ed. 2007, 46, 2768. (c) Marion, N.; Nolan, S. P. Acc. Chem. Res. 2008, 41, 1440. (d) Hahn, F.; Jahnke, M. C. Angew. Chem. Int. Ed. 2008, 47, 3122. (e) Herrmann, W. A. Angew. Chem. Int. Ed. 2002, 41, 1290. (f) Crudden, C. M.; Allen, D. P. Coord. Chem. Rev. 2004, 248, 2247.

2. Christmann, U.; Vilar, R. Angew. Chem. Int. Ed. 2005, 44, 366.

3. (a) A. J. Arduengo, A. J.; Krafczyk, R.; Schmutzler, R.; Craig, H. A.; Goerlich, J. R.; Marshall, W. J.; Unverzagt, M. Tetrahedron 1999, 55, 14523. (b) Jafarpour, L.; Stevens, E. D.; Nolan, S. P. J. Organomet. Chem. 2000, 606, 49. (c) Hintermann, L. Beilstein J. Org. Chem. 2007, 3, 22. 
4. (a) Laitar, D. S.; Müller, P.; Sadighi, J. P. J. Am. Chem. Soc. 2005, 127, 17196-17197. (b) Tsui, E.; Müller, P.; Sadighi, J. Angew. Chem. Int. Ed. 2008, 47, 8937-8940. (c) Nolte, C.; Mayer, P.; Straub, B. F. Angew. Chem. Int. Ed. 2007, 46, 2101-2103. (d) Berthon-Gelloz, G.; de Bruin, B.; Tinant, B.; Markó, I. E. Angew. Chem. Int. Ed., 2009, 48, 3161-3164.

5. (a) Hillier, A. C.; Sommer, W. J.; Yong, B. S.; Petersen, J. L.; Cavallo, L.; Nolan, S. P. Organometallics 2003, 22, 4322-4326. (b) Poater, A.; Cosenza, B.; Correa, A.; Giudice, S.; Ragone, F.; Scarano, V.; Cavallo, L. Eur. J. Inorg. Chem. 2009, 1759-1766. (c) Cavallo, L.; Correa, A.; Costabile, C.; Jacobsen, H. J. Organomet. Chem. 2005, 690, 5407-5413.

6. Dröge, T.; Glorius, F. Angew. Chem. Int. Ed. 2010, 49, 6940-6953.

7. Clavier, H.; Nolan, S. P. Chem. Commun. 2010, 46, 841-861.

8. Altenhoff, G.; Würtz, S.; Glorius, F. Tetrahedron Lett. 2006, 47, 2925-2928.

9. Lavallo, V.; Canac, Y.; Präsang, C.; Donnadieu, B.; Bertrand, G. Angew. Chem. Int. Ed. 2005, 44, 5705-5709.

10. Lavallo, V.; Canac, Y.; De Hope, A.; Donnadieu, B.; Bertrand, G. Angew. Chem. Int. Ed. 2005, 44, 7236-7239.

11. (a) Glorius, F.; Altenhoff, G.; Goddard, R.; Lehmann, C. W. Chem. Commun. 2002, 38, 2704-2705. (b) Altenhoff, G.; Goddard, R.; Lehmann, C. W.; Glorius, F. Angew. Chem., Int. Ed. 2003, 42, 3690-3693. (c) Altenhoff, G.; Goddard, R.; Lehmann, C. W.; Glorius, F. J. Am. Chem. Soc. 2004, 126, 15195-15201. (d) Würtz, S.; Glorius, F. Acc. Chem. Res. 2008, 41, 1523-1533. (e) Würtz, S.; Lohre, C.; Fröhlich, R.; Bergander, K.; Glorius, F. J. Am. Chem. Soc. 2009, 131, 8344-8345.

12. (a) Lavallo, V; Canac, Y.; Präsang, C.; Donnadieu, B.; Bertrand, G. Angew. Chem. Int. Ed., 2005, 44, 5705-5709. (b) Lavallo, V.; Canac, Y.; De Hope, A.; Donnadieu, B.; Bertrand, G. Angew. Chem. Int. Ed. 2005, 44, 7236-7239. (c) Lavallo, G.; Frey, D.; Kousar, S.; Donnadieu, B.; Bertrand, G. Proc. Natl. Acad. Sci. U. S. A. 2007, 104, 13569-13573. (d) Lavallo, V.; Frey, G.; Donnadieu, B.; Soleilhavoup, M.; Bertrand, G. Angew. Chem. Int. Ed. 2008, 47, 5224-5228. (e) Organ, M. G.; Calimsiz, S.; Sayah, M.; Hoi, K. H.; Lough, A. J. Angew. Chem. Int. Ed. 2009, 48, 2383-2387.

13. Arduengo, A. J.; Krafczyk, R.; Schmutzler, R.; Craig, H. A.; Goerlich, J. R.; Marshall, W. J.; Unverzagt, M. Tetrahedron 1999, 55, 14523-14534.

14. Berthon-Gelloz, G.; Siegler, M. A.; Spek, A. L.; Tinant, B.; Reek, J. N. H.; Markó, I. E. Dalton Trans. 2010, 39, 1444-1446.

15. (a) Gómez-Suárez, A. N.; Ramón, R. N. S.; Songis, O.; Slawin, A. M. Z.; Cazin, C. S. J.; Nolan, S. P. Organometallics 2011, 5463-5470. (b) Albright, A.; Eddings, D.; Black, R.; Welch, C. J.; Gerasimchuk, N. N.; Gawley, R. E. J. Org. Chem. 2011, 76, 7341-7351.

16. Tashiro, M.; Yamato, T. J. Org. Chem. 1979, 44, 3037-3041.

17. Yamamoto, H. U.S. Patent Application 20050159607, 2005.

18. Schoeps, D.; Buhr, K.; Dijkstra, M.; Ebert, K.; Plenio, H. Chem. Eur. J. 2009, 15, 29602965.

19. Ortep-3 for Windows: Farrugia, L. J. J. Appl. Cryst. 1997, 30, 565-565. 
20. Persistence of Vision Ray Tracer (POV-Ray), version 3.6, www.povray.org.

21. Dash, C.; Shaikh, M. M.; Ghosh, P. Eur. J. Inorg. Chem. 2009, 2009, 1608.

22. Nasielski, J.; Hadei, N.; Achonduh, G.; Kantchev, E. A. B.; O'Brien, C. J.; Lough, A.; Organ, M. G. Chem. Eur. J. 2010, 16, 10844-10853.

23. Organ, M. G.; Chass, G. A.; Fang, D.-C.; Hopkinson, A. C.; Valente, C. Synthesis 2008, 2776-2797.

24. Buried volumes and second ligand buried volumes were calculated using SambVca

25. (Parameters used for SambVca calculations: (a) $3.50 \AA$ was selected as the value for the sphere radius, (b) $2.00 \AA$ was considered as distances for the metal_ligand bond, (c) usually irrelevant in crystallography, hydrogen atoms were included, and (d) Bondi radii scaled by 1.17 were used): https://www.molnac.unisa.it/

26. Jaguar, version 7.8, Schrodinger, LLC, New York, NY, 2010.

27. (a) Becke, A. D. Phys. Rev. A 1988, 38, 3098-3100. (b) Perdew, J. P. Phys. Rev. B 1986, 33, 8822-8824. (c) Hay, P. J.; Wadt, W. R.; J. Chem. Phys. 1985, 82, 299-310. (d) Ditchfield, R.; Hehre, W. J.; Pople, J. A. J. Chem. Phys. 1971, 54, 724-728. (e) Hariharan, P. C.; Pople, J. A. Theor. Chem. Acc. 1973, 28, 213-222.

28. O'Brien, C. J.; Kantchev, E. A. B.; Valente, C.; Hadei, N.; Chass, G. A.; Lough, A.; Hopkinson, A. C.; Organ, M. G. Chem. Eur. J. 2006, 12, 4743-4748.

29. Marvel, C. S.; Johnston, H. W.; Meier, J. W.; Mastin, T. W.; Whitson, J.; Himel, C. M. J. Am. Chem. Soc. 1944, 66, 914-918.

30. Balfe, M. P.; Kenyon, J.; Thain, E. M. J. Chem. Soc. 1952, 790-796. 